\title{
Sustainable Vegetable Production: Introduction to the Colloquium
}

\author{
John McGrady \\ University of Arizona, Yuma Agricultural Center, 6435 W. 8th Street, Yuma, AZ 85364
}

\begin{abstract}
"Sustainable agriculture" is a term that can mean many things to many people. Generally, most authors and analysts of the meaning of "sustainability" agree that the principal components involve social, economic and ecological relationships at the local or national level (Douglas, 1985; Senanayake, 1991). Recently, Allen et al. (1991), proposed an integrated and "expanded conceptualization of sustainability-one that focuses on the entire food and agriculture system at a global level and includes not only environmental soundness and economicviability, but social equity as well." For the purpose of this colloquium, Harwood's (1990) more narrow concept may be appropriate: "the interrelatedness of all parts of a farming system, including the farmer and his [sic] family; the importance of the many biological balances in the system; the need to minimize use of material and practices that disrupt those relationships." The dialogue on definition(s) of sustainability is certain to continue. For the practitioners, sustainable agriculture is a state of mind and a way of life. "Sustainable agriculture is to conventional agriculture what the Renaissance was to the Dark Ages-a rebirth of hope and discovery, and a change [that] takes place in the head and in the heart" (Strange, 1990).
\end{abstract}

With sustainable agricultural research we recognize once again the unity of the art and science of crop production. Our colloquium participants are dedicated and innovative people of vision who have been fortunate to shed the blinders often handed out with advanced degrees or by the agriculture chemical salespeople. They are not bound within the narrow confines of a single discipline. They attempt holistic analyses of complex production systems; investigation of interactions is essential-they are not just data that complicate reporting of main effects. Farmers are actively involved as peers and no longer regarded as passive recipients of knowledge from the land-grant system. In fact, most landgrant universities have had little information on organic or sustainable production practices to offer to growers. More often than not, the farmer is the one with the knowledge, the innovator. As Sonnabend (1991) states, "I know that I am outstanding in my field; that is sufficient motivation to keep on growing organically."

Sustainable vegetable production does not necessarily mean organic vegetable production. Many growers have made a commitment to create a more sustainable farm for their families and communities. But the immediate elimination of all chemical fertilizers and pesticides would be a disaster for many. In transition from a purely chemical-based production to a more environmentally benign one, economics may dictate the use of a pesticide to save the crop. Time is needed for growers, researchers, and extension agents to become familiar with environmentally sound practices and their efficient implementation.

Conversely, organic vegetable production is not necessarily sustainable. A Yuma, Ariz., grower experimented with organic production on 40 ha of cauliflower and head lettuce. After 2 years of high-quality crops, he dropped the program. The market price did not justify the extra production costs-primarily in biological pest control. This was a highinput organic farm, there was no continuity of soil-improving techniques, limited use of cover crops, and no real commitment to create a sustainable system for the long run. These last four words- "for the long run"- are important. It is essential that administrators recognize the long-term nature of experiments investigating ecological agricultural systems and give credit and time to those involved. Chromosome mapping, gene identification, subsequent genetic alteration, and testing a commercially viable plant are complex, time consuming, expensive, and administratively acceptable. But I submit that sustainable horticulture is equally complex, equally demanding, and an equally worthwhile endeavor.

We have volumes of "literature on the benefits of organic matter and the fixation of N by legumes" (Kelly, 1990). However, we need additional knowledge about the use of legumes and other cover crops as green manures (Stivers and Shennan, 1991), as habitats for predatory insects (Bugg, 1991), as mulches for weed suppression (Wallace and Bellinder, 1991), and in rotational niches for soil improvement (Sarrantonio, 1991). As suggested by Kelly (1990) and Wien (1990), large-scale, long-term, multidisciplinary studies are essential to follow nutrient cycling and seasonal soil microbial activity in traditional monocrop systems (Jackson, 1991), farming systems comparisons (McGrady, et al., 1991; Shennan et al., 1990), and evaluation of crops, rotations, and cultural techniques during transition (Peters, 1991).

Sustainable agriculture encompasses not only the use of the ecological agriculture practices explored by our colloquium participants to sustain the good earth, but also sound socio-economic policies and practices to sustain communities, the family farm, and the farm family.

\section{Literature Cited}

Allen, P., D. VanDusen, J. Lundy, and S. Gliessman. 1991. Integrating social, environmental, and economic issues in sustainable agriculture. Amer. J. Alternative Agr. 6(1):34-39.

Bugg, R.L. 1991. Using cover crops to manage arthropods on truck farms. HortScience 26(6):184 (Abstr.).

Douglas, G.K. 1985. When is agriculture "sustainable"? p. 10-21. In: T. Edens, C. Fridgen, and S. Battenfield (eds.). Sustainable agriculture and integrated farming systems. Michigan State Univ. Press, East Lansing.

Harwood, R.R. 1990. A history of sustainable agriculture, p. 3-19. In: C.A. Edwards, R. Lal, P. Madden, R.H. Miller, and G. House (eds.). Sustainable agriculture systems. Soil and Water Conservation Soc., Ankeny, Iowa.

Jackson, L.E. 1991. Nitrogen nitrate water study. Iceberg Lettuce Res. Program Annu. Rpt., Salinas, Calif. p. 137-151.

Kelly, W.C. 1990. Minimal use of synthetic fertilizers in vegetable production. Proc. Sustainable Commercial Veg. Prod. with Minimal Use of Synthetic Fertilizers and Pesticides, HortScience 25(2):168169.

McGrady, J., M. Matheron, J. Palumbo, M. Rethwisch, M. Butler, J. Matejka, and P. Tilt. 1991. Sustainable lettuce production. 1991 Veg. Rpt. Univ. Arizona College Agr. Ser. P-88:23-28.

Peters, S. 1991. Organic and conventional cropping beyond transition. Organic Farmer 2(1):13-18.

Sarrantonio, M. 1991. Opportunities and challenges for the inclusion of soil-improving crops in vegetable production systems. HortScience 26(6):184. (Abstr.)

Senanayake, R. 1991. Sustainable agriculture: definitions and parameters for measurement. J. Sustainable Agr.1(4):7-28.

Shennan, C., L.E. Drinkwater, A.H.C. van Bruggen, D.K. Letourneau, and F. Workneh. 1990. Comparative study of organic and conventional tomato production systems; an approach to on-farm systems 
studies, p. 109-132. In: J.P. Madden (ed.). Sustainable agriculture research and education in the field. National Academy Press, Washington, D.C.

Sonnabend, Z. 1991. Women in alternative agriculture: words from the west. Organic Farmer 2(3):15.

Stivers, L.J. and C. Sherman. 1991. Meeting the nitrogen needs of processing tomatoes through winter cropping. J. Prod. Agr .4(3):330335 .
Strange, M. 1990. Open letter. Ctr. for Rural Affairs Newsletter, December, Walthill, Neb.

Wallace, R.W. and R.R. Bellinder. 1991. Alternative tillage and herbicide options for successful weed control in vegetables. HortScience 26(6):184. (Abstr.)

Wien, H.C. 1990. Sustainable commercial vegetable production with minimal use of synthetic fertilizers and pesticides: a postlude. HortScience 25(2):170-171. 